\title{
Preparation and characterization of a rechargeable battery based on poly-(3,4-ethylenedioxythiophene) and aluminum in ionic liquids
}

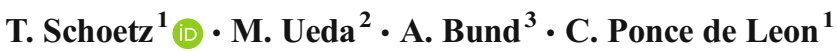

Received: 21 March 2017 /Revised: 21 May 2017 / Accepted: 22 May 2017 /Published online: 17 June 2017

(C) The Author(s) 2017. This article is an open access publication

\begin{abstract}
This paper presents a feasibility study of a nonaqueous rechargeable battery based on aluminum and poly-(3,4-ethylenedioxythiophene) conductive polymer in a chloroaluminate ionic liquid. The polymer was electrodeposited on a vitreous carbon working electrode in a chloride aqueous solution and the structure was analyzed by scanning electron microscopy. The doping/de-doping mechanism of chloride ions into the polymer structure was studied using a quartz crystal microbalance and cyclic voltammetry. The deposition/ dissolution of the aluminum negative electrode were investigated by electrochemical and microscopic methods. Performance data were obtained with a laboratory-scale aluminum-conductive polymer battery at constant current showing an average cell discharge voltage of $1 \mathrm{~V}$ and specific energies of at least $84 \mathrm{Wh} \mathrm{kg}^{-1}$ referred to the mass of the polymer and aluminum. The system is novel and the paper outlines further research to improve the cell performance.
\end{abstract}

Keywords Aluminum · Lewis acidic ionic liquid ·

PEDOT-aluminum battery .

Poly-(3,4-ethylenedioxythiophene) (PEDOT)

T. Schoetz

T.Schoetz@ soton.ac.uk.de

1 Faculty of Engineering and the Environment, University of Southampton, Highfield Southampton SO17 1BJ, Great Britain

2 Faculty of Engineering, Hokkaido University, Kita-13, Nishi-8, Kita-ku, Sapporo, Hokkaido 060-8628, Japan

3 Electrochemistry and Electroplating Group, Technische Universität Ilmenau, Gustav-Kirchhoff-Straße 6, 98693 Ilmenau, Germany

\section{Introduction}

The long-term transformation of our energy landscape will involve high-performance energy storage technologies for sustainable energy sources such as intermittent photovoltaics and wind power. Batteries have currently a minor contribution to the challenges of the energy conversion; however, the continuous growth of sustainable energy sources will require a range of energy storage systems. Therefore, there is an urgent need for R\&D in the state of the art batteries, to develop novel energy storage systems, like rechargeable batteries [1-4].

The main problems of the state of the art batteries, like lithium-based systems, are safety, availability of materials, and costs $[5,6]$. The occurrence of lithium in the earth crust is approximately $20 \mathrm{ppm}$. The increasing demand of lithiumbased batteries will require additional lithium production and recycling [7]. Great effort has been dedicated to improve the specific energy and power of lithium-ion batteries, while less attention has been directed to aluminum batteries in nonaqueous systems [8]. These systems merit study since aluminum is more abundant ( $\sim 80,000 \mathrm{ppm})$, cost-effective, and safer than lithium [9-13]. In addition, the theoretical-specific capacity of aluminum $\left(3.0 \mathrm{Ah} \mathrm{g}^{-1}\right)$ is comparable to that of lithium $\left(3.9 \mathrm{Ah} \mathrm{g}^{-1}\right)[14,15]$; unlike lithium, aluminum batteries are not flammable and are not endangered by thermal runaway, which is still a very serious problem of lithium-ion batteries $[16,17]$.

Rechargeable batteries based on the reversible deposition and dissolution of aluminum in a Lewis acidic chloroaluminate ionic liquid have been reported [14, 18, 19]. Charge storage materials like three-dimensional graphitic foams [18], vanadium pentoxide nano-wires [19], and electro-polymerized polypyrrole and polythiophene [14] in ionic liquid have been used as positive electrodes. The storage mechanism of these materials consists on the reversible 
intercalation of chloroaluminate ion species in the porous three-dimensional structures of the graphitic foam [18] and nano-wires [19], whereas conductive polymers [14] store anions to compensate the positive charges in the oxidized polymer backbone. These battery systems showed high reversibility as well as stable electrochemical behavior of the charge storage materials (graphitic foams, nano-wires, and conductive polymers) as positive electrodes with high coulombic efficiencies approaching $100 \%$. Cell voltages between $0.55 \mathrm{~V}$ [19] and $2 \mathrm{~V}$ [18] were reached with a wide electrochemical stability window [20], allowing the reversible redox reaction of aluminum ( $0 \mathrm{~V}$ vs $\mathrm{Al} / \mathrm{Al}(\mathrm{III})$ [21]). The delivered specific discharge capacities are $70 \mathrm{Ah} \mathrm{kg}^{-1}$ (graphitic foam) [18], 273-305 $\mathrm{Ah} \mathrm{kg}^{-1}$ (vanadium pentoxide nano-wires) [19], and 30-100 $\mathrm{Ah} \mathrm{kg}^{-1}$ (conductive polymers) [14]. The reported specific capacities compete with those observed during the performance of positive active materials for lithiumion batteries $\left(50-300 \mathrm{Ah} \mathrm{kg}^{-1}\right.$ [6]).

\section{Proposed battery system}

The battery proposed in this paper is based on the reversible deposition and dissolution of aluminum at the negative electrode while the conductive polymer PEDOT is doped and dedoped with chloride ions at the positive electrode in a Lewis acidic chloroaluminate ionic liquid.

In contrast to the use of bulky chloroaluminate anions as dopant described in the previous section [14, 18, 19], this work uses chloride ions as the dopant species for the conductive polymer that has been previously electro-polymerized in an aqueous solution. Chloride anions as dopant are preferred because they are smaller and more mobile than bulky chloroaluminate ions [20]. Furthermore, the smaller size of chloride ions could provide higher charge/discharge rates and high storage capacity.

The conductive polymer poly-(3,4-ethylenedioxythio phene) (PEDOT), used in this work, offers the advantageous characteristics of conventional polymers and high metal-like conductivity $[22,23]$. This heterocyclic conducting polymer has a low oxidation potential in aqueous solutions ( $\sim 1 \mathrm{~V}$ vs SHE [24]) and it is stable in the oxidized state as a $p$-type semiconductor. In addition, conductive polymers are called hybrid capacitors because they have the ability to store large amount of charge while acting as capacitor and battery at the same time [25]. PEDOT is able to store additional amount of charges by increasing the oxidation potential (doping potential). The amount of additional stored charges depends on the thickness and porosity of the film. Hybrid capacitors are potentially positive electrode materials for high-performance batteries, which require high capacities and cell potentials.

The charging reaction of PEDOT (Eq. 1), which is represented by one EDOT monomer, is an oxidation process from the neutral to the positively charged state and the simultaneous insertion of anions (doping). The oxidation causes positive-charged centers (sulfur or carbon) in the polymer backbone, which are compensated by the doping anions $\left(\mathrm{Cl}^{-}, \mathrm{AlCl}_{4}^{-}, \mathrm{Al}_{2} \mathrm{Cl}_{7}^{-}\right)$of the ionic liquid. Chloride anions are preferred as doping/de-doping species because of their small size and high mobility. The discharge reaction (Eq. 1) comprises the release of anions into the electrolyte and the transfer of the conductive polymer to the neutral state. The oxidation and reduction of PEDOT is characterized by a one electron transfer reaction.

$$
\begin{gathered}
{[\mathrm{EDOT}]_{1 / a}+\mathrm{X}^{-} \underset{\text { discharge }}{\stackrel{\text { charge }}{\leftarrow}}[\mathrm{EDOT}]_{1 / a} \mathrm{X}+\mathrm{e}^{-} \mathrm{X}^{-}} \\
=\mathrm{Cl}^{-}, \mathrm{AlCl}_{4}^{-}, \mathrm{Al}_{2} \mathrm{Cl}_{7}^{-}
\end{gathered}
$$

The degree of doping $(\alpha)$ is the ratio between the number of inserted chloride ions $\left(n_{\mathrm{Cl}}{ }^{-}\right)$and the number of monomer units $\left(n_{\mathrm{EDOT}^{+}}\right)$(Eq. 2$)$. The degree of doping varies from 0 to 1 .

$\alpha=\frac{n\left(\mathrm{Cl}^{-}\right)}{n\left(E D O T^{+}\right)}$

The reversible deposition and dissolution of aluminum (Eq. 3) at the negative electrode is possible in a Lewis acidic chloroaluminate ionic liquid, containing heptachloro dialuminate ions $\left(\mathrm{Al}_{2} \mathrm{Cl}_{7}^{-}\right)[20,26-36]$.

$4 \mathrm{Al}_{2} \mathrm{Cl}_{7}^{-}+3 \mathrm{e}^{-} \underset{\text { discharge }}{\stackrel{\text { charge }}{\leftarrow}} \mathrm{Al}+7 \mathrm{AlCl}_{4}^{-}$

A Lewis basic chloroaluminate ionic liquid is composed of tetrachloroaluminate ions $\left(\mathrm{AlCl}_{4}{ }^{-}\right)$and the organic cation compound 1-ethyl-3-methylimidazolium $\left(\mathrm{EMIm}^{+}\right)$. The $\mathrm{AlCl}_{4}{ }^{-}$ions are reduced at potentials more negative than the organic cation $\mathrm{EMIm}^{+}$. Therefore, $\mathrm{EMIm}^{+}$would be decomposed before the deposition of aluminum [20]. In order to avoid this decomposition, Lewis acidic mixtures of 1-ethyl3-methylimidazolium chloride ([EMIm]Cl) and aluminum chloride $\left(\mathrm{AlCl}_{3}\right)$ are prepared to favor the formation of $\mathrm{Al}_{2} \mathrm{Cl}_{7}^{-}$(Eq. 4) [36]:

$2 \mathrm{AlCl}_{4}^{-} \rightleftharpoons \mathrm{Al}_{2} \mathrm{Cl}_{7}^{-}+\mathrm{Cl}^{-}$

The heptachlorodialuminate $\mathrm{Al}_{2} \mathrm{Cl}_{7}{ }^{-}$anion forms when the molar ratio of $\mathrm{AlCl}_{3}$ to the ionic liquid [EMIm] Cl is higher than unity (Lewis acidic ionic liquid). The deposition of aluminum from $\mathrm{Al}_{2} \mathrm{Cl}_{7}^{-}$occurs before the decomposition of the ionic liquid. 
The overall reaction of the battery (Eq. 5) arises from the half-cell reactions (Eqs. 1 and 3):

$$
3 E D O T_{1 / \alpha}+4 \mathrm{Al}_{2} \mathrm{Cl}_{7}^{-} \rightleftharpoons 3 E D O T_{1 / \alpha}^{+}+\mathrm{Al}+7 \mathrm{AlCl}_{4}^{-}
$$

A theoretical maximum specific capacity of $36 \mathrm{Ah} \mathrm{kg}^{-1}$ is calculated by using the overall reaction (Eq. 5) and a degree of doping $\alpha$ of 0.33 , which is a typical value for PEDOT [23].

In this feasibility study, we propose a secondary nonaqueous aluminum-based battery operating at room temperature. The PEDOT-aluminum battery connects the two independent reactions, the reversible intercalation (doping/de-doping) of PEDOT with chloride anions and deposition and dissolution of aluminum in a Lewis acidic chloroaluminate ionic liquid in an advanced novel approach.

\section{Experimental}

\section{Preparation of PEDOT electrodes}

The monomer 3,4-ethylenedioxythiophene (EDOT) (purity $>98.0 \%)$ and potassium chloride $(>99.5 \%)$ were supplied by Wako Chemicals. The PEDOT electrodes were prepared in a three-electrode cell at $28{ }^{\circ} \mathrm{C}$ and ambient atmosphere in an aqueous solution containing $0.01 \mathrm{~mol} \mathrm{dm}^{-3}$ EDOT and $\mathrm{KCl}$ from 0.01 to $1.0 \mathrm{~mol} \mathrm{dm}^{-3}$. EDOT was potentiostatically electro-polymerized at $1.2 \mathrm{~V}$ vs $\mathrm{Ag} / \mathrm{AgCl}$ for $30 \mathrm{~min}$ on a planar vitreous carbon working electrode (WE) $\left(4.5 \mathrm{~cm}^{2}\right)$. A solid platinum plate electrode $\left(0.5 \mathrm{~cm}^{2}\right)$ was used as counter electrode $(\mathrm{CE})$ and silver/silver chloride as reference electrode (RE) (Ag/ $\mathrm{AgCl} 3 \mathrm{~mol} \mathrm{dm}^{-3}, 0.197 \mathrm{~V}$ vs SHE). The inter-electrode distance between the WE and CE was $1 \mathrm{~cm}$. The RE was connected by a salt bridge filled with agar-agar powder (Wako, jelly strength $400 \sim 600 \mathrm{~g} \mathrm{~cm}^{-2}$ ) over a HaberLuggin capillary tube with the cell. The distance between the tip of the capillary and WE was $0.3 \mathrm{~cm}$. The cell potential was controlled with a potentiostat (BioLogic SP-240), using the commercial software package ECLAB (version 10.32). After the deposition, the PEDOT films were dried in vacuum for at least 3 days. The mass of the vitreous carbon electrodes was measured in dried condition before and after electro-polymerization with an electrical balance (Sartorius, $\pm 0.1 \mathrm{mg}$ ) to determine the deposited mass of PEDOT doped with chloride ions. The doped amount of chloride ions was calculated by the difference of the initial amount of chloride ions in the electro-polymerization solution and the remaining amount of chloride ions in the electro-polymerization solution after the polymerization. The remaining amount of chloride was determined by Mohr titration [37, 38]. The degree of doping $(\alpha)$ (Eq. 2) can be determined by the ratio between the amount of doped chloride ions $\left(n_{\mathrm{Cl}}{ }^{-}\right)$ and the amount of EDOT monomers $\left(n_{\mathrm{EDOT}}\right)$. The accuracy of the calculated degree of doping depends on the measured deposited mass of the polymerized and doped PEDOT film as well as on the measured amount of doped chloride ions by Mohr titration. In order to assess the accuracy of these values, the titration measurements were repeated at least five times.

\section{Electrochemical characterization}

The Lewis acidic ionic liquid $(33.3 \mathrm{~mol} \%$ [EMIm] $\mathrm{Cl}$ and $66.7 \mathrm{~mol} \% \mathrm{AlCl}_{3}$ ) was prepared by adding $87.64 \mathrm{~g}$ aluminum chloride (Kanto Chemicals, 98\%) to $48.11 \mathrm{~g}$ 1-ethyl-3methylimidazolium chloride (Merck, for synthesis) under continuous stirring and cooling, resulting in a translucent light yellow color liquid. The preparation of the ionic liquid and the half-cell tests and galvanostatic charging and discharging experiments in ionic liquid were performed in a glove box in an argon atmosphere $(99.999 \%$ ) with less than $50 \mathrm{ppm}$ water content. The ionic liquid EMIm- $\mathrm{AlCl}_{3}$ is stable at a water content lower than $500 \mathrm{ppm}[18]$.

The cyclic voltammetry $(\mathrm{CV})$ experiments were performed in a cylindrical three-electrode glass cell $\left(9.4 \mathrm{~cm}^{3}\right)$ with an aluminum wire (1 mm diameter, $99.99 \%)$ as reference electrode. The inter-electrode distance between the rectangular counter electrode (vitreous carbon, $4.5 \mathrm{~cm}^{2}$ ) and rectangular working electrode (either PEDOT or aluminum with 99.99\%, $4.5 \mathrm{~cm}^{2}$ ) was $0.4 \mathrm{~cm}$. The electrodes were placed parallel to each other. The same cell was used for galvanostatic charge and discharge experiments of the PEDOT-aluminum battery. The battery was galvanostatically discharged at $-0.02 \mathrm{~mA} \mathrm{~cm}^{-2}$ and charged at $0.2 \mathrm{~mA} \mathrm{~cm}^{-2}$. The cell was additionally equipped with a commercially available porous (pore size range of 0.03 to $0.8 \mathrm{~mm}$ ) glass frit as support for the electrolyte solution, which was soaked with ionic liquid and placed between the electrodes. The thickness of the electrolyte support was $0.4 \mathrm{~cm}$. The experiments were performed with and without the electrolyte support and the results compared.

The polymer can be doped with a mixture of anions $\left(\mathrm{Cl}^{-}\right.$, $\mathrm{AlCl}_{4}{ }^{-}, \mathrm{Al}_{2} \mathrm{Cl}_{7}{ }^{-}$) in the ionic liquid electrolyte. For this reason, in situ quartz crystal microbalance (QCM) measurements in chloroaluminate electrolytes were performed to determine the molar mass of the doping species. A gold-coated quartz crystal $\left(10 \mathrm{MHz}\right.$; active crystal area $(A) 0.2 \mathrm{~cm}^{2}$; density $(\rho)$ $2.64 \mathrm{~g} \mathrm{~cm}^{-3}$; shear modulus $(\mu) 2.95 \times 10^{11} \mathrm{~g} \mathrm{~cm}^{-1} \mathrm{~s}^{-2}$ ) was used as substrate for constant potential electro-polymerization of PEDOT films as working electrode at $1.2 \mathrm{~V} \mathrm{vs} \mathrm{Ag} / \mathrm{AgCl}$ for $600 \mathrm{~s}$ in aqueous $0.01 \mathrm{~mol} \mathrm{dm}^{-3}$ EDOT and $0.1 \mathrm{~mol} \mathrm{dm}^{-3} \mathrm{KCl}$ solution.

For the doping and de-doping experiments, a cylindrical cell with aluminum wires (1 mm diameter, $99.99 \%)$ as counter 
and reference electrodes was used. The resonant frequency $(f)$, including the initial resonant frequency $\left(f_{0}\right)$, of the quartz crystal was measured in argon atmosphere (water level $<0.5 \mathrm{ppm}$, oxygen level $0.2 \mathrm{ppm}$ ) in ionic liquid electrolyte and before and after the measurement in absence of the electrolyte. Simultaneously, cyclic voltammetry measurements, from 0 to $2 \mathrm{~V}$ vs $\mathrm{Al} / \mathrm{Al}(\mathrm{III})$, were performed to calculate the transferred anodic and cathodic charges. The cyclic voltammogram was first recorded in anodic and then in cathodic direction. The Sauerbrey equation (Eq. 6) [39] was used to determine the mass changes $(\Delta m)$.

$\Delta f=-\frac{2 f_{0}^{2}}{\sqrt{\mu \rho}} \cdot \frac{\Delta m}{A}$

\section{Structural characterization}

The structure of the aluminum electrodes and PEDOT electrodes, prepared at different molar ratios of $\mathrm{KCl}(0.01$ to $\left.1.0 \mathrm{~mol} \mathrm{dm}^{-3}\right)$ and EDOT $\left(0.01 \mathrm{~mol} \mathrm{dm}^{-3}\right)$, was investigated by a JEOL JSM-6510LA scanning electron microscope (SEM). Their elemental composition was analyzed through an energy-dispersive X-ray (EDX) module (EX-230 BM). The images were taken with a secondary electron detector at different magnifications (max. 40,000), 5-20 kV, and WD 9 to $29 \mathrm{~mm}$. All EDX spectra were measured at a magnification of $1500,10 \mathrm{kV}$, WD $10 \mathrm{~mm}$, and around $5000 \mathrm{cps}$. Poorly conductive samples were sputtered with gold at $30 \mathrm{~mA}$ for $30 \mathrm{~s}$.

\section{Results and discussion}

\section{Structure of electro-polymerized PEDOT}

The SEM images (Fig. 1) of the PEDOT surfaces prepared by potentiostatic electro-polymerization in $0.01 \mathrm{~mol} \mathrm{dm}^{-3}$ EDOT and 0.01 to $1.0 \mathrm{~mol} \mathrm{dm}^{-3} \mathrm{KCl}$ show that PEDOT forms a granular and porous structure on vitreous carbon. These porous grains have a high surface area and consequently a high number of accessible positive charged doping positions for chloride ions.

The structure of the PEDOT films, prepared in an increasing concentration of $\mathrm{KCl}$ in the electro-polymerization solution, strongly depends on the doping anion concentration. The density of the grains increases significantly with increasing

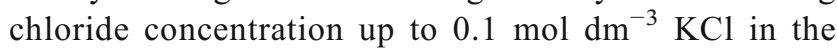
electro-polymerization solution (Fig. 1a-c). The structure and grain density remains similar for electrodes prepared in solutions with 0.1 to $1.0 \mathrm{~mol} \mathrm{dm}^{-3} \mathrm{KCl}$ (Fig. 1c, d).

The distribution of the grains, which were polymerized in aqueous solution containing $0.1 \mathrm{~mol} \mathrm{dm} \mathrm{dm}^{-3} \mathrm{KCl}$ and $0.01 \mathrm{~mol} \mathrm{dm}^{-3}$ EDOT, is very uniform at the surface of the vitreous carbon substrate (Fig. 1c). The randomly distributed agglomerates of PEDOT have an average size of 0.2 to $2 \mu \mathrm{m}$. The formation of three-dimensional grains on top of an initial uniform layer of the conductive polymer is typical for the material because of the higher adhesion of the agglomerates on a first thin layer of PEDOT than on the native vitreous carbon substrate [40-42]. The average ratio of the proportion of sulfur, which represents one monomer unit of EDOT per one chloride ion, was measured by EDX. The ratio
Fig. 1 SEM images of PEDOT deposited at $1.2 \mathrm{~V}$ vs $\mathrm{Ag} / \mathrm{AgCl}$ for $30 \mathrm{~min}$ on vitreous carbon $\left(4.5 \mathrm{~cm}^{2}\right)$ in $0.01 \mathrm{~mol} \mathrm{dm}^{-3}$ EDOT and a $0 \mathrm{~mol} \mathrm{dm}^{-3} \mathrm{KCl}, \mathbf{b}$ $0.01 \mathrm{~mol} \mathrm{dm}^{-3} \mathrm{KCl}, \mathbf{c}$ $0.1 \mathrm{~mol} \mathrm{dm}^{-3} \mathrm{KCl}$, and $\mathbf{d}$ $0.5 \mathrm{~mol} \mathrm{dm}^{-3} \mathrm{KCl}$
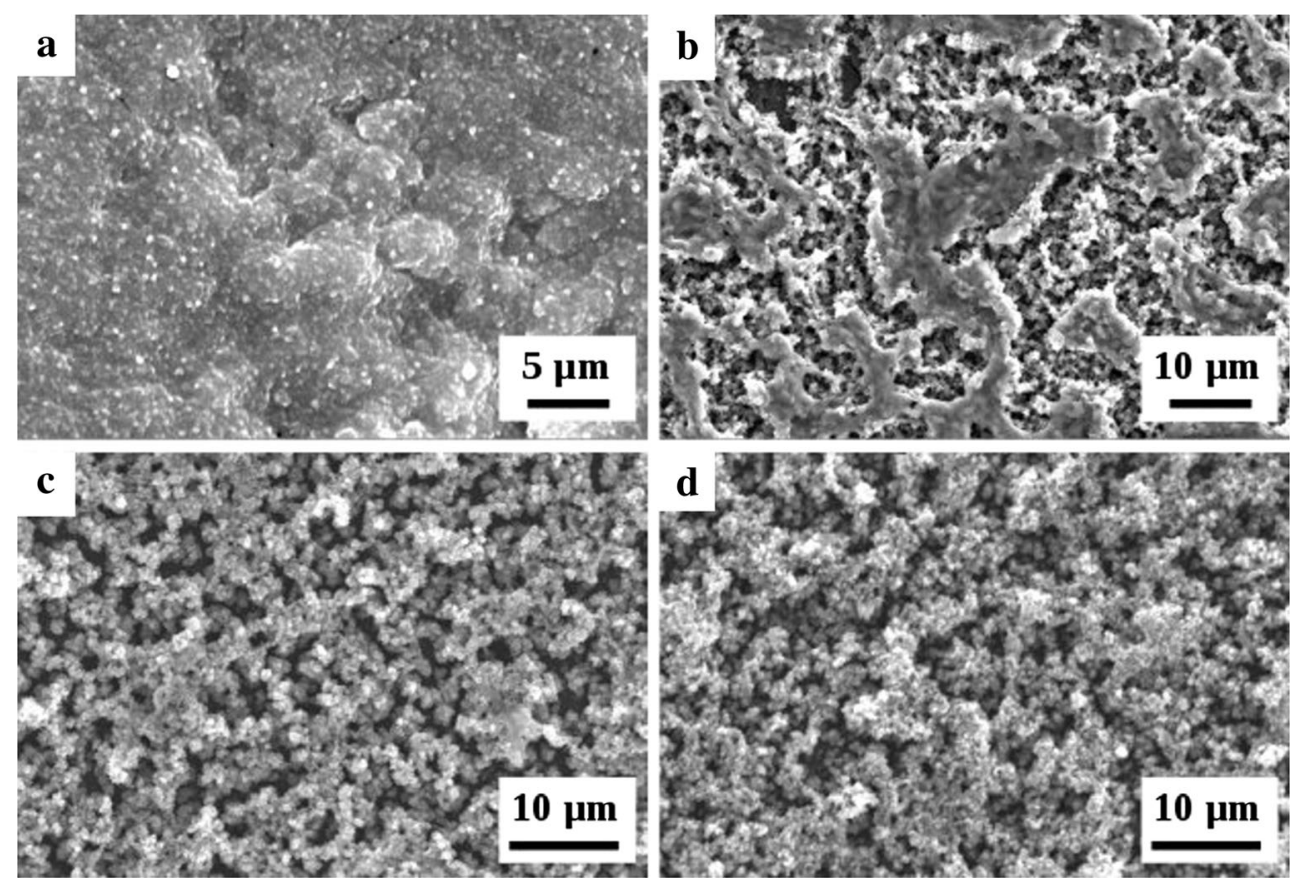
corresponds to a degree of doping of 0.33 and is in accordance with literature value [23].

Undoped PEDOT (Fig. 1a), which was polymerized in $0.01 \mathrm{~mol} \mathrm{dm}^{-3} \mathrm{EDOT}$ and in the absence of $\mathrm{KCl}$, is characterized by a smooth surface with very small and separated grains. A small amount of chloride ions $\left(0.01 \mathrm{~mol} \mathrm{dm}^{-3}\right)$ (Fig. 1b) increases the growth of the grains, covering the whole surface (Fig. 1b-d). Agglomerated grains as well as flat structures were formed over the whole surface of the carbon electrode. The diffusion zones around the hemispherical nuclei have started to overlap, forming the agglomerated grain structure until a critical height of the layers is reached. The height might depend on the concentration of the doping anion. Therefore, the growth continues laterally and flat structures are formed. The formation of a dense structure of grains is attributable to the fact that the conductivity of the solution increases with the chloride concentration. The structures polymerized at a low chloride concentration $\left(0.01 \mathrm{~mol} \mathrm{dm}^{-3} \mathrm{KCl}\right)$ show presumably the initial stage of the PEDOT layer formation. However, the polymerization continues if the oxidation potential remains sufficiently high to oxidize further EDOT to the radical cation. With an insufficient conductivity, the diffusion zones increase until the oxidation current cannot be maintained and the polymerization stops.

\section{Cyclic voltammetry of PEDOT}

The cyclic voltammograms (Fig. 2) of the PEDOT films, prepared in different concentrations of the doping component, show a clear influence of the amount of doping component on the capacity. Each cyclic voltammogram shows a constant capacity beyond cycle 10 . Therefore, cycle 10 was used to compare peak positions and capacity.

The cyclic voltammogram of the PEDOT film prepared in the lowest $\mathrm{KCl}$ concentration of $0.01 \mathrm{~mol} \mathrm{dm}^{-3}$ (Fig. 2 (a)) shows neither anodic nor cathodic peaks. Thus, under these conditions, the PEDOT film seems to be electrochemically inactive. The PEDOT film polymerized in $0.1 \mathrm{~mol} \mathrm{dm}^{-3}$ $\mathrm{KCl}$ (Fig. 2 (b)) is characterized by significant anodic and cathodic peaks as well as high capacity. A further increase of the doping component, to $0.5 \mathrm{~mol} \mathrm{dm}^{-3}$ (Fig. 2 (c)) and $1.0 \mathrm{~mol} \mathrm{dm}^{-3} \mathrm{KCl}$ (Fig. 2 (d)) solution, shows lower currents compared to the film prepared in $0.1 \mathrm{~mol} \mathrm{dm}^{-3}$ (Fig. 2 (b)) $\mathrm{KCl}$. The shapes and the currents and consequently the capacities of the films deposited in 0.5 and $1.0 \mathrm{~mol} \mathrm{dm}^{-3} \mathrm{KCl}$ (Fig. 2 (c, d)) do not show significant differences. From these results, it can be suggested that the amount of chloride ions incorporated in the PEDOT film reaches a maximum. Regarding the decreasing current and capacity from the solutions containing 0.5 and $1.0 \mathrm{~mol} \mathrm{dm}^{-3}$ chloride, it is assumed that an increasing saturation of the positive charges with doping anions in the polymer backbone transforms PEDOT into a less conductive state. The degree of doping, determined by Mohr titration [37,

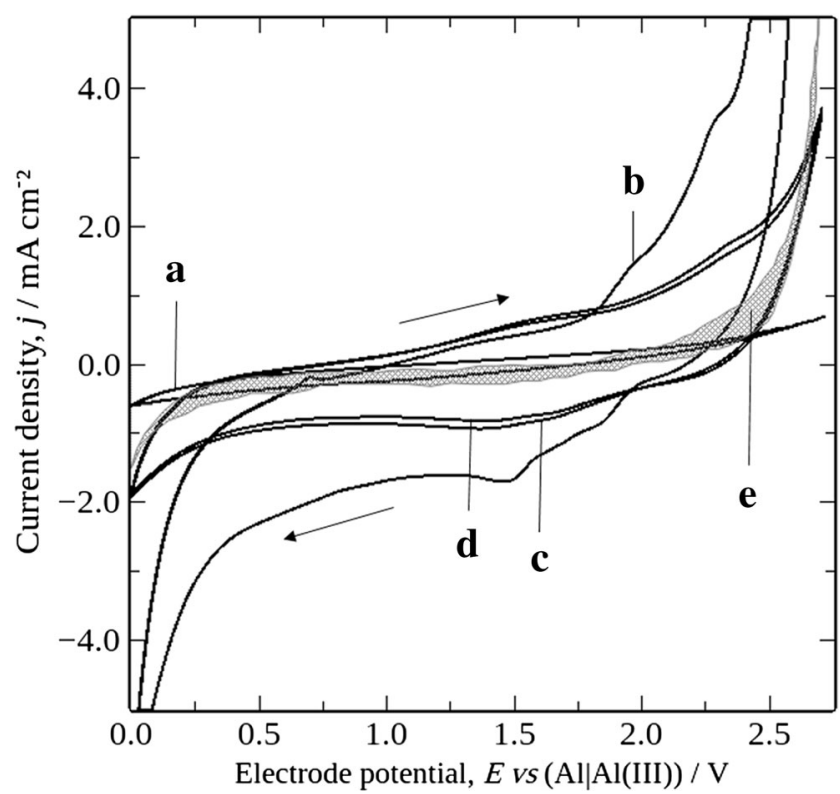

Fig. 2 Cyclic voltammogram of the system PEDOT $\left(4.5 \mathrm{~cm}^{2}\right)$ (WE), vitreous carbon $\left(4.5 \mathrm{~cm}^{2}\right)(\mathrm{CE})$, and aluminum (RE) in Lewis acidic ionic liquid at $100 \mathrm{mV} \mathrm{s}^{-1}$, cycle 10 , and $28^{\circ} \mathrm{C}$. PEDOT film deposited at $1.2 \mathrm{~V}$ vs $\mathrm{Ag} / \mathrm{AgCl}$ for $30 \mathrm{~min}$ in $0.01 \mathrm{~mol} \mathrm{dm}^{-3}$ EDOT and $a$ $0.01 \mathrm{~mol} \mathrm{dm}^{-3} \mathrm{KCl}, b 0.1 \mathrm{~mol} \mathrm{dm}^{-3} \mathrm{KCl}, c 0.5 \mathrm{~mol} \mathrm{dm}^{-3} \mathrm{KCl}$, and $d$ $1.0 \mathrm{~mol} \mathrm{dm}{ }^{-3} \mathrm{KCl}$. $e$ Bare vitreous carbon (WE, CE, $4.5 \mathrm{~cm}^{2}$ ) and aluminum (RE) in Lewis acidic ionic liquid

38], increases with an increasing chloride concentration in the electro-polymerization electrolyte from 0.1 to 0.33 . For the PEDOT film polymerized in $0.01 \mathrm{~mol} \mathrm{dm}^{-3}$ EDOT and $0.1 \mathrm{~mol} \mathrm{dm}^{-3} \mathrm{KCl}$, a degree of doping of 0.27 was determined, along with the highest capacity in the cyclic voltammogram (Fig. 2 (b)). The PEDOT films polymerized in $0.01 \mathrm{~mol} \mathrm{dm}^{-3}$ EDOT and $0.5 \mathrm{~mol} \mathrm{dm}^{-3}$ as well as $1.0 \mathrm{~mol} \mathrm{dm}^{-3}$ (Fig. 2 (c, d)) have a degree of doping of 0.33 , which agrees with the EDX results.

\section{Performance of PEDOT in Lewis acidic ionic liquid}

The cyclic voltammograms of PEDOT electrodes (prepared with $0.01 \mathrm{~mol} \mathrm{dm}^{-3}$ EDOT and $0.1 \mathrm{~mol} \mathrm{dm}^{-3} \mathrm{KCl}$ ) in a Lewis acidic ionic liquid from 0 to $2.7 \mathrm{~V}$ vs $\mathrm{Al} / \mathrm{Al}$ (III) were recorded at 10, 25, and 50 cycles (Fig. 3). A vitreous carbon electrode was used as counter electrode and an aluminum wire as reference electrode. The oxidation and reduction reactions of the film in the Lewis acidic ionic liquid are characterized by four anodic and three cathodic waves, indicating different levels of doping and de-doping of the polymer. The anodic broad waves arise at $0.7 \mathrm{~V}$ (I), $1.45 \mathrm{~V}$ (II), $1.9 \mathrm{~V}$ (III), and $2.2 \mathrm{~V}$ (IV) vs Al/Al(III). The doping at $2.2 \mathrm{~V}$ (IV) occurs with the decomposition of the ionic liquid to chlorine gas. The cathodic wave around $1.85 \mathrm{~V}(\mathrm{~V})$ correlates with the anodic wave at $1.9 \mathrm{~V}$ (III) vs $\mathrm{Al} / \mathrm{Al}$ (III) and indicates a reversible doping and de-doping reaction. The second cathodic wave 


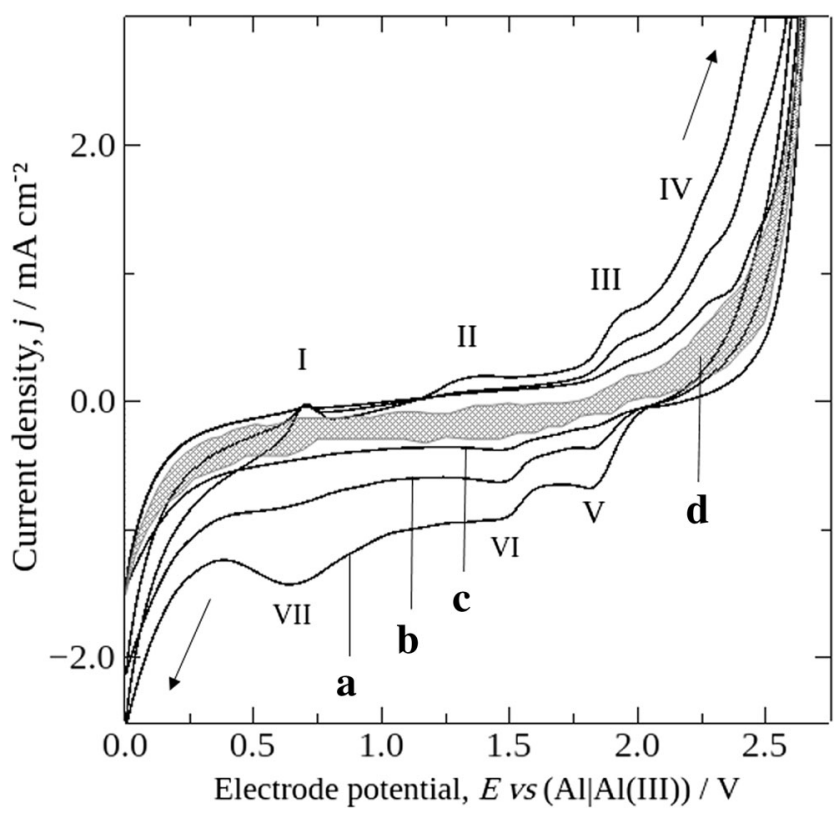

Fig. 3 Cyclic voltammogram of the system PEDOT $\left(4.5 \mathrm{~cm}^{2}\right)$ (WE), vitreous carbon $\left(4.5 \mathrm{~cm}^{2}\right)(\mathrm{CE})$, and aluminum (RE) in Lewis acidic ionic liquid at $100 \mathrm{mV} \mathrm{s}^{-1}$, different cycle numbers $a$ cycle $10, b$ cycle 25 , and $c$ cycle 50 , and $28^{\circ} \mathrm{C} . d$ Bare vitreous carbon (WE, CE, $4.5 \mathrm{~cm}^{2}$ ) and aluminum (RE) in Lewis acidic ionic liquid

appears at $1.5 \mathrm{~V}(\mathrm{VI})$ and the third wave arises at $0.7 \mathrm{~V}(\mathrm{VII})$ vs $\mathrm{Al} / \mathrm{Al}(\mathrm{III})$.

With an increasing cycle number, the anodic and cathodic currents decrease. A swelling of the PEDOT film was observed in the ionic liquid during doping and de-doping, which appears as blue cloud-like film around the electrode that causes the decrease in current, as there are less available active sites to accommodate chloride ions in the PEDOT backbone. The polymer film loses its adhesion on the vitreous carbon substrate and is partially detached. The stability of the polymer on the substrate can be improved by using rougher surfaces and three-dimensional carbon substrates to deposit PEDOT or by using pure porous PEDOT electrodes, as they are more stable due to the higher number of doping positions in contrast to flat thin films of PEDOT on the vitreous carbon surface. This approach will be a focus of future work.

\section{Determination of the anion doping species}

PEDOT films doped with chloride ions were formed on a gold-coated crystal quartz electrode of $0.2 \mathrm{~cm}^{2}$ area by polymerization of $0.01 \mathrm{~mol} \mathrm{dm}^{-3}$ EDOT in $0.1 \mathrm{~mol} \mathrm{dm}^{-3} \mathrm{KCl}$ aqueous solution at a constant potential of $1.2 \mathrm{~V}$ vs Ag/ $\mathrm{AgCl}$ for $600 \mathrm{~s}$. The quartz with the PEDOT film were dried and transferred into a Lewis acidic ionic liquid and cycled from 0 to $2.0 \mathrm{~V}$ vs Al/Al(III) (Fig. 4 (a)). Simultaneously, the changes of the resonance frequency [39] (different resonance frequencies of the loaded and unloaded quartz crystal) $(\Delta f)$ of the quartz crystal were measured (Fig. 4 (b)).

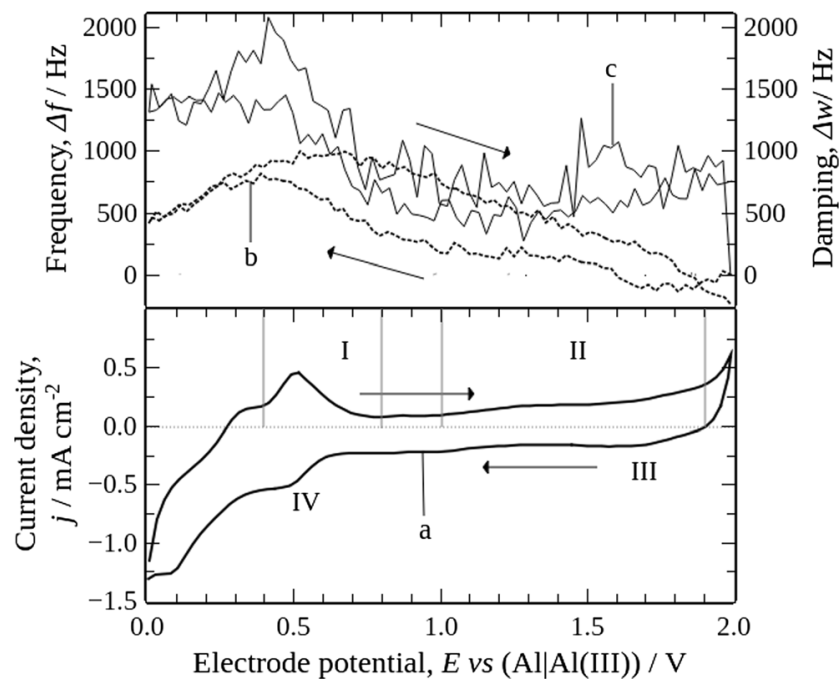

Fig. $4 a$ Current density, $b$ change of resonance frequency $(\Delta f$, dotted line), and $c$ change of damping ( $\Delta w$, solid line) depending on potential of the system PEDOT $\left(0.2 \mathrm{~cm}^{2}\right)$ on a gold resonator (WE) and aluminum wire (CE and RE) in Lewis acidic ionic liquid at $100 \mathrm{mV} \mathrm{s}^{-1}$ and $28^{\circ} \mathrm{C}$

PEDOT could also been doped with $\mathrm{AlCl}_{4}{ }^{-}$and $\mathrm{Al}_{2} \mathrm{Cl}_{7}{ }^{-}$ ions, which are present in the ionic liquid electrolyte, during cycling. The changes in mass $(\Delta m)$, calculated by the changes in resonance frequency $(\Delta f)$ with the Sauerbrey equation (Eq. 6), and the transferred anodic and cathodic charges $(\Delta Q)$ (Table 1) provide information about the doping species.

The regions I and II (Table 1) indicate the doping potential window $(\Delta E)$ of PEDOT. The mass change $(\Delta m)$ of the polymer, determined by quartz crustal microbalance measurement (Fig. 4 (b)), in these regions, refers to doped anion species. The transferred charge $(\Delta Q)$ was measured simultaneously with cyclic voltammetry (Fig. 4 (a)). The specific charge $\left(Q_{\text {spec }}\right)$ was calculated by the ratio of $\Delta Q$ and $\Delta m$. The cyclic voltammogram (Fig. 4 (a)) shows anodic waves from 0.4 to $0.8 \mathrm{~V}$ (I) and 1.0 to $1.9 \mathrm{~V}$ (II) vs Al/Al(III). The frequency $(\Delta f)$ decreases approximately linearly at these anodic potentials (Fig. 4 (b)), which indicates the anion doping (p-doping) [39]. The subsequent cathodic waves from 1.4 to $1.8 \mathrm{~V}$ (III) and 0.35 to $0.65 \mathrm{~V}$ (IV) vs $\mathrm{Al} / \mathrm{Al}(\mathrm{III})$ show the de-doping

Table 1 Calculated values for molar mass $\left(M_{\text {doped anion }}\right)$ of the doped and de-doped anion species in PEDOT, electro-polymerized on the gold electrode of a quartz crystal, in the listed potential ranges $(\Delta E)$ of the cyclic voltammogram (Fig. 4$)$. The specific charges $\left(\Delta Q_{\text {spec }}\right)$ were determined by the transferred charges $(\Delta Q)$ measured by cyclic voltammetry and change of mass $(\Delta m)$ of the polymer film calculated by the change of frequency of the resonator by Sauerbrey equation

\begin{tabular}{llllll}
\hline $\begin{array}{l}\text { Potential } \\
\text { window }\end{array}$ & $\Delta E(\mathrm{~V})$ & $\Delta m(\mathrm{~g})$ & $\Delta Q(\mathrm{~mA} \mathrm{~s})$ & $\begin{array}{l}\Delta Q_{\text {spec }} \\
\left(\mathrm{As} \mathrm{g}^{-1}\right)\end{array}$ & $\begin{array}{l}M_{\text {doped }} \\
\text { anion } \\
\left(\mathrm{g} \mathrm{mol}^{-1}\right)\end{array}$ \\
\hline I & $0.4-0.8$ & $2.9 \times 10^{-7}$ & 0.2 & 690 & 140 \\
II & $1.0-1.9$ & $2.9 \times 10^{-7}$ & 0.3 & 1103 & 87 \\
\hline
\end{tabular}


reaction, which also represents the increase of the frequency. PEDOT can be also doped with cations ( $n$-doping) when the polymer carries negative charges. It is assumed that the cationic species EMIm ${ }^{+}$is inserted in the PEDOT film from 0 to $0.4 \mathrm{~V}$ vs Al/Al(III). The oxidation shows an increase of the frequency in the same potential range, indicating a decrease of mass or removal of the cationic species.

The doping and de-doping reactions occur in the potential window 0.4 to $1.9 \mathrm{~V}$ vs $\mathrm{Al} \mid \mathrm{Al}(\mathrm{III})$ (Table 1). As the damping changes $(\Delta w)$ (Fig. 4 (c)) of the quartz crystal in this potential window are in the same order of magnitude as the frequency changes (Fig. 4 (b)), we can use the Sauerbrey equation (Eq. 6) to calculate the change of mass from the change of frequency. The calculated molar mass $\left(M_{\text {doped anion }}\right)$ for the doped anion species are 140 and $87 \mathrm{~g} \mathrm{~mol}^{-1}$ (Table 1), indicating that the doping proceeds via a mixture of $\mathrm{Cl}^{-}$ $\left(M_{\text {theo }}=35.6 \mathrm{~g} \mathrm{~mol}^{-1}\right)$ and $\mathrm{AlCl}_{4}{ }^{-}\left(M_{\text {theo }}=169.4 \mathrm{~g} \mathrm{~mol}^{-1}\right)$ (Table 1). It is assumed that bulky chloroaluminate ions are partially trapped and irreversibly inserted in the polymer film and causing a damage with subsequent detachment of the PEDOT film, which was observed as blue cloud-like film in the electrolyte ("Performance of PEDOT in Lewis acidic ionic liquid" section). The selective doping of PEDOT with smaller chloride ions might be realized in a Lewis basic ionic liquid, which contains an excess of free chloride ions.

\section{Performance of aluminum dissolution and deposition in Lewis acidic ionic liquid}

A Lewis acidic ionic liquid of [EMIm] $\mathrm{Cl}$ and $\mathrm{AlCl}_{3}$ contains an excess of $\mathrm{AlCl}_{3}$, which enables the electro-deposition of aluminum. The cyclic voltammogram (Fig. 5) shows the tenth cycle of the deposition and dissolution of aluminum on aluminum plate $\left(4.5 \mathrm{~cm}^{2}\right)$ between $-0.5 \mathrm{~V}$ and $0.5 \mathrm{~V} \mathrm{vs} \mathrm{Al} / \mathrm{Al}(\mathrm{III})$.

The reduction of the complex aluminum ion $\left(\mathrm{Al}_{2} \mathrm{Cl}_{7}^{-}\right)$ starts at $-0.175 \mathrm{~V}$ vs $\mathrm{Al} / \mathrm{Al}(\mathrm{III})$. The deposition occurs with some over potential due to the nucleation process, which has been reported for many metals in ionic liquids [35]. The aluminum oxidation is characterized by a wide peak with a maximum around $0.25 \mathrm{~V}$ vs $\mathrm{Al} / \mathrm{Al}(\mathrm{III})$. The stripping peak shows an anodic charge of $5.3 \mathrm{mC} \mathrm{cm}{ }^{-2}$ whereas the charge of the cathodic electro-deposition is $7 \mathrm{mC} \mathrm{cm}^{-2}$ giving a stripping efficiency of $76 \%$. The stripping efficiency remains approximately constant with the cycles of the cyclic voltammetry. It is assumed that the reduced stripping efficiency is caused by the formation of a porous deposit of ionic liquid compounds on the aluminum electrode surface (Fig. 6), inhibiting the oxidation of aluminum. However, the deposition and dissolution of aluminum in a Lewis acidic ionic liquid is acceptable and can be improved [26] and therefore suitable for the charging and discharging reactions of the PEDOT-aluminum system.

The deposition of aluminum in the Lewis acidic ionic liquid shows a very porous surface (pore diameter $\sim 0.4$ to

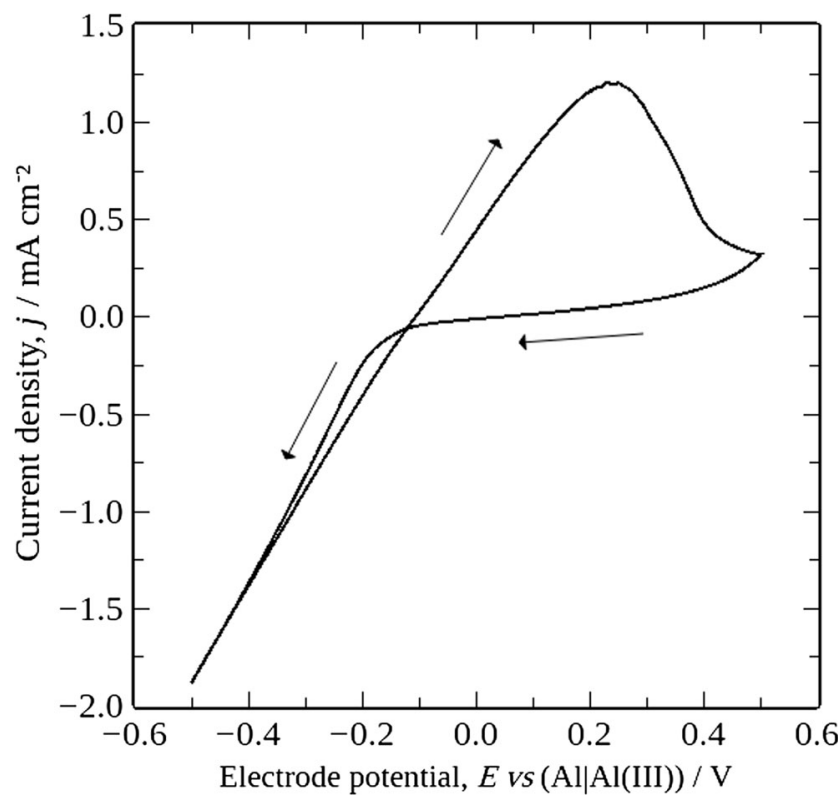

Fig. 5 Cyclic voltammogram of a Lewis acidic ionic liquid with aluminum $\left(4.5 \mathrm{~cm}^{2}\right)$ (WE), vitreous carbon $\left(4.5 \mathrm{~cm}^{2}\right)(\mathrm{CE})$, and aluminum (RE) at $100 \mathrm{mV} \mathrm{s}^{-1}$, cycle 10 , and $28^{\circ} \mathrm{C}$

$1.4 \mu \mathrm{m}$ ) (Fig. 6a) on the aluminum electrode and circular deposits with a diameter of $\sim 28 \mu \mathrm{m}$ (Fig. 6b). It is proposed that the circular deposits are organic decomposition products

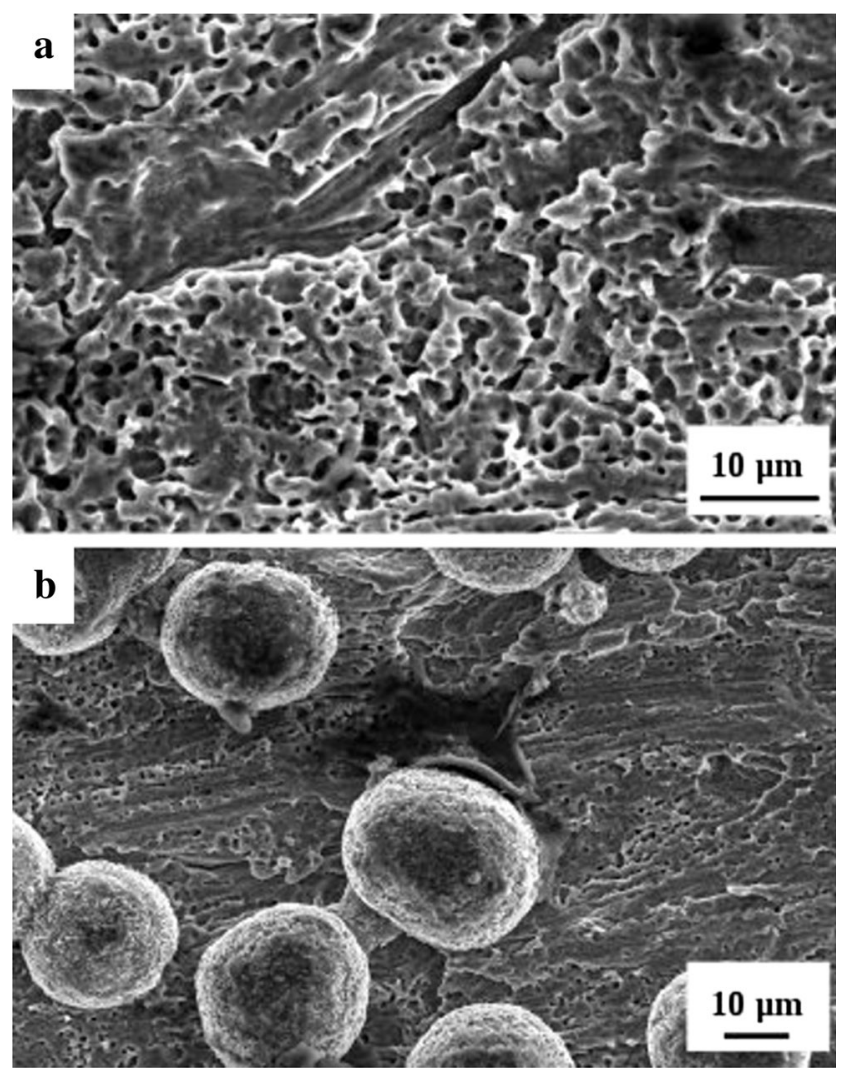

Fig. 6 SEM images of the aluminum electrode surface a with porous deposit and $\mathbf{b}$ circular deposits after cyclic voltammetry in Lewis acidic ionic liquid 
of the ionic liquid, because the cyclic voltammetry was carried out until $-0.5 \mathrm{~V}$ vs $\mathrm{Al} \mid \mathrm{Al}(\mathrm{III})$. The aluminum deposition occurs at potentials lower than $-0.2 \mathrm{~V}$ vs $\mathrm{Al} \mid \mathrm{Al}(\mathrm{III})$ and the ionic liquid decomposition process starts at $-0.5 \mathrm{~V}$. Furthermore, the porous structure may be a thin film of organic depositions or decomposition products as well, which are permeable for aluminum ions.

\section{Charge and discharge behavior of PEDOT-aluminum battery}

The reference sample, prepared in $0.01 \mathrm{~mol} \mathrm{dm}^{-3}$ EDOT and $0.1 \mathrm{~mol} \mathrm{dm}^{-3} \mathrm{KCl}$ supported on vitreous carbon plate $\left(4.5 \mathrm{~cm}^{2}\right)$, was introduced as the positive electrode and metallic aluminum plate $\left(4.5 \mathrm{~cm}^{2}\right)$ was used as negative electrode in the cell. The open circuit potential was measured before the galvanostatic cycling and before every charge and discharge cycle (Eqs. 1 and 3). The OCP before the first cycle is between 2.1 and $2.3 \mathrm{~V}$ and before cycle 2 to 10 between 1.3 and $1.6 \mathrm{~V}$. The battery was galvanostatically discharged (Fig. $7(\mathrm{a}, \mathrm{c})$ ) at $-0.02 \mathrm{~mA} \mathrm{~cm}^{-2}$ and charged (Fig. 7 (b)) at $0.2 \mathrm{~mA} \mathrm{~cm}^{-2}$.

The average cell voltage of the first discharge is $2 \mathrm{~V}$ for $124 \mathrm{~mA} \mathrm{~s}$ (Fig. 7 (a)). The first charge voltage is around 2.2 to $2.3 \mathrm{~V}$ for $1600 \mathrm{~mA} \mathrm{~s}$ (Fig. 7 (b)). The beginning of the charging curve after $1500 \mathrm{~s}$ shows a steep slope at 1.8 to $1.9 \mathrm{~V}$. Assuming that the aluminum deposition is at $0 \mathrm{~V} \mathrm{vs} \mathrm{Al} / \mathrm{Al}(\mathrm{III})$, the slope and the voltage plateau correlate with the peaks at 1.9 to $2.0 \mathrm{~V}$ and $2.2 \mathrm{~V} \mathrm{vs} \mathrm{Al} / \mathrm{Al}(\mathrm{III})$ in the cyclic voltammogram (Fig. 3 potential regions III and IV), indicating the

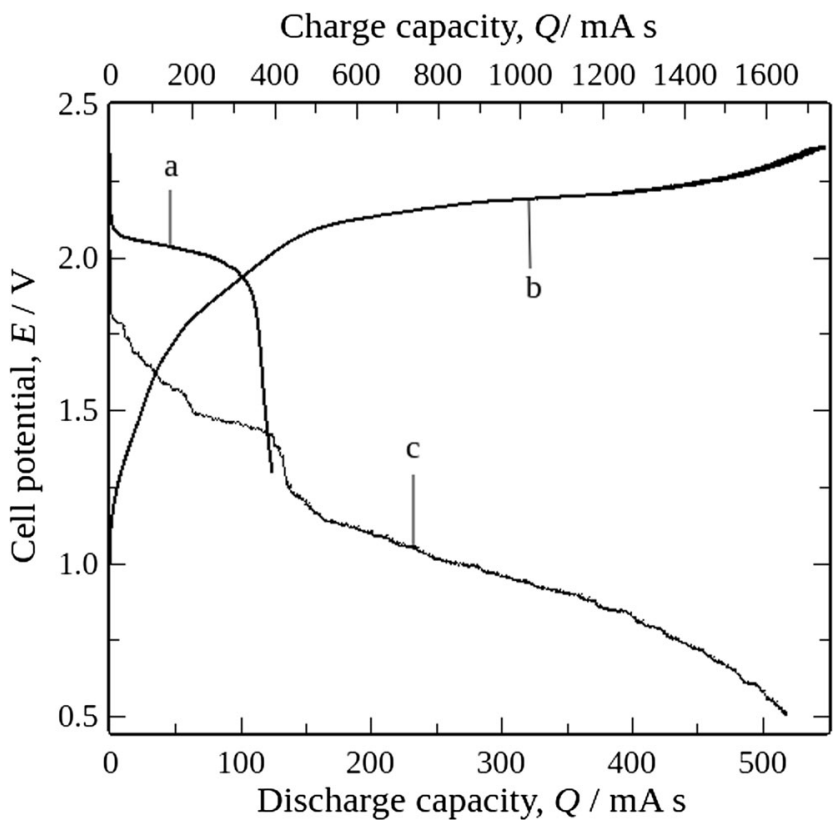

Fig. 7 Galvanostatic discharging at $-0.02 \mathrm{~mA} \mathrm{~cm}^{-2}$ and charging at $0.22 \mathrm{~mA} \mathrm{~cm}^{-2}$ of the system PEDOT-aluminum in Lewis acidic ionic liquid at $28^{\circ} \mathrm{C}$. $a$ First discharge cycle, $b$ second charge cycle, and $c$ second discharge cycle doping of chloride ions in the polymer. The charging cycle (Fig. 7 (b)) was terminated at $2.35 \mathrm{~V}$ because the electrolyte started to decompose. The subsequent discharge curve (Fig. 7 (c)) is characterized by a decreasing cell voltage from around 1.2 to $0.8 \mathrm{~V}$ for around $170 \mathrm{mAs}$ and terminated at $0.5 \mathrm{~V}$. The suggestion is that the first discharge is accompanied by the dedoping of chloride ions and the subsequent charge is characterized by the doping of $\mathrm{AlCl}_{4}{ }^{-}$in the polymer, influencing the OCP, discharge voltage, and capacity. In addition, the insertion of bulky ions like $\mathrm{AlCl}_{4}{ }^{-}$in the polymer could change the structure of the polymer film and cause a damage of the film and a loss of active mass.

The battery-related characteristics (Table 2), which are based on the deposited mass of PEDOT, the active mass of aluminum, applied discharge current, and discharge time, show a specific capacity of $84 \mathrm{Ah} \mathrm{kg}^{-1}$. This is 2.3 times higher than the maximum theoretical value. This discrepancy can be explained if it is assumed that the PEDOT electrode behaves like a capacitor and battery (also known as hybridcapacitor). The sum of the non-faradaic cathodic-specific charges $\left(52 \mathrm{Ah} \mathrm{kg}^{-1}\right)$, obtained from the second cycle of the cyclic voltammogram (Fig. 3) of PEDOT in Lewis acidic ionic liquid, and the maximum theoretical capacity $\left(36 \mathrm{Ah} \mathrm{kg}^{-1}\right)$ equals approximately to the measured specific capacity $\left(84 \mathrm{Ah} \mathrm{kg}^{-1}\right)$. This additional capacity is probably provided by the capacitive double layer of anion species $\left(\mathrm{Cl}^{-}, \mathrm{AlCl}_{4}^{-}\right.$, $\mathrm{Al}_{2} \mathrm{Cl}_{7}{ }^{-}$) and cationic species $\left(\mathrm{EMIm}^{+}\right.$) of the electrolyte.

\section{Influence on the charge and discharge behavior with porous electrolyte support}

In order to limit the loss of PEDOT mass due to swelling and detachment of the film from the electrode, a porous support for the electrolyte was used. The aim was to keep the PEDOT film as close as possible to the vitreous carbon electrode. The pore size was between 0.03 and $0.8 \mathrm{~mm}$ to allow the ions in

Table 2 Comparison of battery characteristic values without and with electrolyte support. List of measured deposited mass ( $\left.m_{\text {active }}\right)$ of PEDOT and active mass of aluminum and OCP of the system PEDOT-aluminum as well as capacity $(Q)$ calculated from the discharge time and the applied current, specific charge $\left(Q_{\text {spec }}\right)$ calculated by the capacity per mass, specific power $\left(P_{\text {spec }}\right)$ calculated by the average discharge voltage of $1 \mathrm{~V}$, and the applied current per mass and specific energy $\left(E_{\mathrm{spec}}\right)$ calculated by the average discharge voltage, applied current, and discharge time per active mass

\begin{tabular}{lllllll}
\hline & $\begin{array}{l}m_{\text {active }} \\
(\mathrm{mg})\end{array}$ & $\begin{array}{l}\text { OCP } \\
(\mathrm{V})\end{array}$ & $\begin{array}{l}Q \\
(\mathrm{~mA} \mathrm{~s})\end{array}$ & $\begin{array}{l}Q_{\text {spec }} \\
\left(\mathrm{Ah} \mathrm{kg}^{-1}\right)\end{array}$ & $\begin{array}{l}P_{\text {spec }} \\
\left(\mathrm{W} \mathrm{kg}^{-1}\right)\end{array}$ & $\begin{array}{l}E_{\text {spec }} \\
\left(\mathrm{Wh} \mathrm{kg}^{-1}\right)\end{array}$ \\
\hline $\begin{array}{c}\text { Without } \\
\text { electrolyte } \\
\text { support }\end{array}$ & 0.6 & 2.0 & 170 & 84 & 179 & 84 \\
$\begin{array}{c}\text { With } \\
\text { electrolyte } \\
\text { support }\end{array}$ & 0.7 & 1.6 & 600 & 228 & 143 & 228 \\
\hline
\end{tabular}


the ionic liquid to move freely and maintain the ionic conductivity. In this new configuration, the PEDOT-aluminum system in Lewis acidic ionic liquid was galvanostically charged and discharged at 0.2 and $-0.02 \mathrm{~mA} \mathrm{~cm}^{-2}$, respectively. The second discharge cycles without (Fig. 8 (a)) and with (Fig. 8 (b)) electrolyte support were compared.

The discharge reaction for the cell with the porous electrolyte support is characterized by a significant longer discharge plateau over $600 \mathrm{~mA}$ s between 1.1 and $0.9 \mathrm{~V}$ (Fig. 8 (b)). The discharging was terminated at $0.9 \mathrm{~V}$ because of the low practical use of this cell potential. The cell with electrolyte support was charged between 2.2 and $2.3 \mathrm{~V}$ for $1600 \mathrm{~mA}$ s similar to the charging cycle of the cell without electrolyte support (Fig. 7 (b)). The coulombic efficiency is $38 \%$ for the cell with electrolyte support. The cell shows a discharge time, specific charge and capacity that are approximately three times larger (Table 2) than the cell without electrolyte support. The calculated energy densities, based on the active mass of aluminum and deposited mass of PEDOT, are $84 \mathrm{Wh} \mathrm{kg}^{-1}$ without electrolyte support and $228 \mathrm{Wh} \mathrm{kg}^{-1}$ with electrolyte support, which is in the order of nickel-metal-hydride batteries $(60$ $100 \mathrm{Wh} \mathrm{kg}^{-1}$ ) and lithium-based battery systems (100$\left.256 \mathrm{Wh} \mathrm{kg}^{-1}\right)$, respectively [43]. The improved performance is due to the fact that the film was kept in place by the electrolyte support and the behavior of PEDOT as hybrid capacitor. A more porous conductive polymer electrode reaches a higher capacity due to proportional capacitance to sample volume. Future work will aim at a deeper understanding of whether the measured values were caused by the battery system or are an effect of the porous electrolyte support.

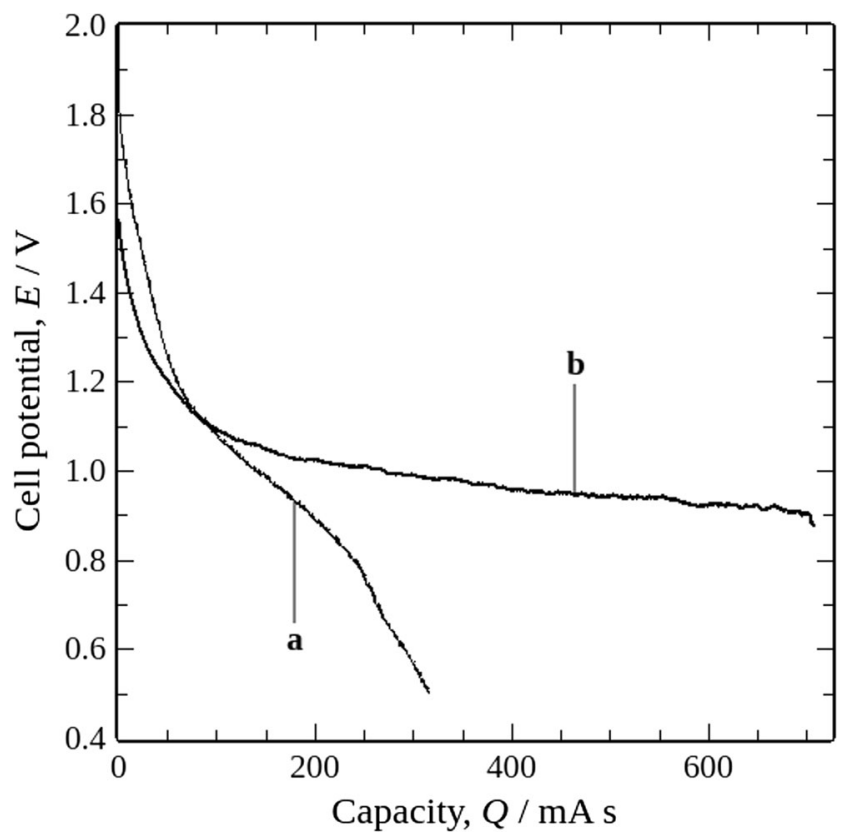

Fig. 8 Galvanostatic discharging at $-0.02 \mathrm{~mA} \mathrm{~cm}^{-2} a$ without separator and $b$ with separator of the system PEDOT-aluminum in Lewis acidic ionic liquid at $28^{\circ} \mathrm{C}$

\section{Conclusions}

This work shows the feasibility of a rechargeable low-cost, novel, and safer PEDOT-aluminum battery system in a Lewis acidic ionic liquid, which was the premier aim of the study.

The system is based on the doping/de-doping of the conductive polymer PEDOT with ions from the ionic liquid and the deposition/dissolution of aluminum.

It has been shown that

(a) The deposition and dissolution of aluminum as negative electrode is reversible with $76 \%$ coulombic efficiency.

(b) The oxidation/reduction and simultaneous doping/dedoping of PEDOT as positive electrode are also reversible.

(c) The doping of PEDOT involves chloride ions and bulky chloroaluminate ions $\left(\mathrm{AlCl}_{4}^{-}\right.$and $\left.\mathrm{Al}_{2} \mathrm{Cl}_{7}^{-}\right)$from the Lewis acidic ionic liquid.

(d) Loss of capacity and low coulombic efficiency occur due to the damage and detachment of the thin and planar PEDOT film during the doping with bulky ions. This can be avoided by using porous substrates for the conductive polymer and selective doping with smaller anions in a Lewis basic chloroaluminate ionic liquid at the positive electrode.

(e) Specific energy and power of $84 \mathrm{Wh} \mathrm{kg}^{-1}$ and $179 \mathrm{~W} \mathrm{~kg}^{-1}$, respectively, in the absence of an electrolyte support and $228 \mathrm{Ah} \mathrm{kg}^{-1}$ and $143 \mathrm{~W} \mathrm{~kg}^{-1}$, respectively, with electrolyte support have been determined. These are comparable with nickel-metal-hydride batteries (without electrolyte support) and with lithium-based battery systems (with electrolyte support).

Acknowledgements This study was supported by the Faculty of Engineering of the Hokkaido University (Japan) during the academic visit by the first author T.S., in cooperation with the Technische Universität Ilmenau (Germany). T.S. is grateful to the Centre for Doctoral Training in Sustainable Infrastructure Systems from the University of Southampton [EP/L01582X/1] and the Lloyd's Register Foundation for the financial support received from September 2016.

Open Access This article is distributed under the terms of the Creative Commons Attribution 4.0 International License (http:// creativecommons.org/licenses/by/4.0/), which permits unrestricted use, distribution, and reproduction in any medium, provided you give appropriate credit to the original author(s) and the source, provide a link to the Creative Commons license, and indicate if changes were made.

\section{References}

1. Droste-Franke B (2012) Balancing renewable electricity, ethics of science and technology assessment 40. Springer-Verlag, Berlin, Heidelberg 
2. Divya KC, Østergaard J (2009) Battery energy storage technology for power systems - an overview. Electr Power Syst res 79:511520

3. Hall PJ, Bain EJ (2008) Energy-storage technologies and electricity generation. Energy Policy 36:4352-4355

4. Denholm P, Ela E, Kirby B (2010) The role of energy storage with renewable electricity generation. Technical report NREL/TP-6A247187: 1-61.

5. Scrosati B, Garche J (2010) Lithium batteries: status, prospects and future. J Power Sources 195:2419-2430

6. Korthauer R (2013) Handbook lithium-ion-batteries. SpringerVerlag, Berlin, Heidelberg

7. Mohr SH, Mudd GM, Giurco D (2012) Lithium resources and production: critical assessment and global projections. Fortschr Mineral 2:65-84

8. Hu M, Pang X, Zhou Z (2013) Recent progress in high-voltage lithium ion batteries. J Power Sources 237:229-242

9. Grosjean C, Herrera Miranda P, Perrin M, Poggi P Assessment of world lithium resources and consequences of their geographic distribution on the expected development of the electric vehicle industry. Renew Sust Energ Rev 16:1735-1744.

10. Kesler SE, Gruber PW, Medina PA (2012) Global lithium resources: relative importance of pegmatite, brine and other deposits. Ore Geol rev 48:55-69

11. Mohr SH, Mudd GM, Giurco D (2012) Lithium resources and production: critical assessment and global projections. Fortschr Mineral 2:65-84

12. Hosterman JW, Patterson SH, Good (1990) World nonbauxite aluminium resources excluding alunite. U.S. Geological Survey, Alexandria VA.

13. Rauch JN (2009) Global mapping of $\mathrm{Al}, \mathrm{Cu}, \mathrm{Fe}$ and $\mathrm{Zn}$ in-use stocks and in-ground resources. U.S. Geological Survey, Reston VA

14. Hudak NS (2014) Chloroaluminate-doped conducting polymers as positive electrodes in rechargeable aluminium batteries. J Phys Chem 118:5203-5215

15. Julien C (2015) Lithium batteries. Springer International Publishing, Cham

16. Tobishima S, Yamaki J (1999) A consideration of lithium cell safety. J Power Sources 81-82:882-886

17. Biensan P, Simon B, Pérès JP (1999) On safety of lithium-ion cells. J Power Sources 81-82:906-912

18. Lin M, Gong M, Lu B (2015) An ultrafast rechargeable aluminumion battery. Nature 520:324-328

19. Jayaprakash N, Das SK, Archer LA (2011) The rechargeable aluminium-ion battery. Chem Commun 47:12610-12612

20. Galiński M, Lewandowski A, St pniak I (2006) Ionic liquids as electrolytes. Electrochim Acta 51:5567-5580

21. Fox D, De Long HC, Trulove PC (2009) Molten salts and ionic liquids 16. Physical and Analytical Electrochemistry ECS Transactions:397-409

22. Senthil Kumar S, Mathiyarasu J, Phani KLN (2005) Simultaneous determination of dopamine and ascorbic acid on poly $(3,4-$ ethylenedioxythiophene) modified glassy carbon electrode. J Solid State Electrochem 10:905-913

23. Heinze J, Frontana-Uribe BA, Ludwigs S (2010) Electrochemistry of conducting polymers-persistent models and new concepts. Chem rev:4724-4771

24. Berthold M, Guth U, Peipmann R, Bund A (2007) Electrogravimetric ion analysis of poly(3,4-ethylenedioxy thiophene) films in aqueous electrolytes. Dresdner Contributions for Sensor Technology:161-164
25. Park JH, Park OO (2002) Hybrid electrochemical capacitors based on polyaniline and activated carbon electrodes. Journal of Power Sources: $185-190$.

26. Ueda M, Hariyama S, Ohtsuka $\mathrm{T}$ (2012) Al electroplating on the

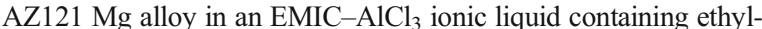
ene glycol. J Solid State Electrochem:3423-3427

27. Hariyama S, Ueda M, Ohtsuka T (2011) Electroplating temperature for $\mathrm{Al}$ plating on $\mathrm{Mg}$ alloy in $\mathrm{AlCl}_{3}$-EMIC ionic liquid. $62^{\text {nd }}$ Annual Meeting of International Society of Electrochemistry.

28. Ueda M, Tabei Y, Ohtsuka T (2010), Surface finishing of Mg alloys by $\mathrm{Al}$ electroplating in $\mathrm{AlCl}_{3}$-EMIC ionic liquid. Electrochemical Society Organic Electrochemistry.

29. Ueda M, Koichi U (2008/2009) Aluminum and aluminum alloy electrodeposition in low-temperature molten salts and roomtemperature ionic liquids. Journal of the Surface Finishing Society of Japan:491-496

30. Czarnecki P, Ahrens M, Schubert T (2015) Ionic liquids and applications as electrolytes for aluminium deposition. Oberflächen.

31. Wilkes JS, Levisky JA, Wilson RA (1982) Dialkylimidazolium chloroaluminate melts: a new class of room-temperature ionic liquids for electrochemistry, spectroscopy and synthesis. Inorg Chem 21:1263-1264

32. Jiang T, Chollier Brym MJ, Dubé G (2006) Electrodeposition of aluminium from ionic liquids: part I electrodeposition and surface morphology of aluminium from aluminium chloride $\left(\mathrm{AlCl}_{3}\right)$-1-ethyl-3-methylimidazolium chloride $([\mathrm{EMIm}] \mathrm{Cl})$ ionic liquids. Surf Coat Technol 201:1-9

33. Zhang S, Sun N, He X (2006) Physical properties of ionic liquids: database and evaluation. J Phys Chem ref Data 35:1475

34. Lee J, Tae Bae I, Scherson DA (2000) Underpotential deposition of aluminum and alloy formation on polycrystalline gold electrodes from $\mathrm{AlCl}_{3} / \mathrm{EMIC}$ room-temperature molten salts. J Electrochem Soc 147:562-566

35. Pradhan D, Reddy RG (2014) Mechanistic study of Al electrodeposition from EMIC- $\mathrm{AlCl}_{3}$ and $\mathrm{BMIC}-\mathrm{AlCl}_{3}$ electrolytes at low temperature. Mater Chem Phys 143:564-569

36. Liu QX, Zein El Abedin S, Endres F (2006) Electroplating of mild steel by aluminium in a first generation ionic liquid: a green alternative to commercial Al-plating in organic solvents. Surf Coat Technol 201:1352-1356

37. Kolthoff JM (1917) The titration of chlorides by Mohr and application for the examination of drinking water. Journal for Analytical Chemistry 56:498-504

38. Freiser H (1992) Concepts and calculations in analytical chemistry. A Spreadsheet Approach CRC Press 196

39. Ispas A, Peipmann R, Bund A (2009) On the p-doping of PEDOT layers in various ionic liquids studied by EQCM and acoustic impedance. Electrochim Acta 54:4668-4675

40. Hyo Cho S, Park S (2006) Electrochemistry of conductive polymers 39. Contacts between conducting polymers and noble metal nanoparticles studied by current-sensing atomic force microscopy. Journal of Physical Chemistry B 110: 25656-25664.

41. Dang X, Dante M, Nguyen T (2008) Morphology and conductivity modification of poly $(3,4$-ethylenedioxy-thiophene): poly(styrenesulfonate) films induced by conductive atomic force microscopy measurements. Appl Phys Lett 93:241911

42. Timpanaro S, Kemerink M, Touwslager FJ (2004) Morphology and conductivity of PEDOT/PSS films studied by scanning-tunneling microscopy. Chem Phys Lett 394:339-343

43. Yang M, Hou J (2012) Membranes in lithium ion batteries. Membranes 2:367-383 